\title{
How the Soviet Union Influence the Change of Personnel System in Chinese Universities
}

\author{
Xiao Xing-An \\ School of Public Management, Yunnan University of Finance and Economics, \\ Kunming,P. R. China ,650221 \\ (466258063@qq.com)
}

\begin{abstract}
The personnel system in Chinese universities is influenced by the Soviet Union. The biggest influence of the Soviet Union is the macro management system, namely, the department management, the plan and centralized management in higher education, the division of the universities and the academy of science. The influence of the microstructure is as follows:firstly,the establishment of the teaching and research section changed the form of the organizations at the grass-roots level in Chinese universities; secondly, the disappearance of the private universities made the faculty and staff in universities became the civil servants.; thirdly, the teachers can only be sent to the Soviet Union and the socialist countries in the Eastern Europe to study, and the teacher evaluation emphasized the teaching; Fourthly , the workload system was introduced and the teachers were classified according to the major. The imitation of the Soviet Union,such as the set up of the Ministry of the higher education and the academic title system ends in failure.
\end{abstract}

Keywords: Chinese universities, the personnel system, the Soviet Union,the influence

\section{Introduction}

Chinese universities is imported, the personnel system of Chinese universities is influenced by the foreign universities more or less.

The change of the personnel system of Chinese universities is characteristic of the grafting and transplantation of the system .And since the late Qing Dynasty, the development of Chinese universities has been a response to the needs of the society,not its own evolution, therefore, the personnel system of Chinese universities is the result of outside force from the origin to every big change of the personnel system. This kind of institutional change from the outside force, make the change path be short of rule. When the old dynasty was replaced with a new one, the personnel system of Chinese universities would have a institutional fracture. Because of the backwardness of China's higher education ,Chinese universities always actively learn from the foreign correspondence on their own during different periods, this makes the personnel system of foreign universities become one of the most important factors that can influence the Chinese universities. In this paper, the influence of the personnel system of the Soviet Union will be mainly discussed.

\section{The Influence of the Soviet Union on the Macro} Management System in Chinese Universities

The greatest influence of the Soviet Union on the personnel system of China's higher education is the macro management system. In December 1949. the first national education conference after the new People's Republic of China was built In the early put forward "on the basis of education experience of the old liberated area, absorb the useful experience of the old education, with the help of the experience of the Soviet Union, build a new democratic education". Actually, during the period that the old universities were received in 1949-1952, the "Old education" were basically denied overall, learning from the Soviet Union became the dominant principle that the People's Republic of China reestablish its education. Firstly, the highly centralized and unified higher education management system adapted with the 
planned economy system was set up. It is characteristic of the close link between the education plan and the national economy plan.The State Council stipulated "The teaching in colleges and universities is under the unified leadership of higher education department. The construction plan, financial plan, financial regulations, personnel system, teaching plan, syllabus, production practice discipline and other important laws and regulations, instructions or command issued by the higher education department,should be implemented by all the universities."

Secondly, the divisional management system of higher education was set up.All the colleges and universities were divided into local universities and universities under the leadship of the ministries. And the universities under the leadship of the ministries were divided into the universities subordinate to the Ministry of Education and the other industry department.So the linear management system of higher education was established. This linear management system of higher education became the theme of the higher education system reform, until the end of the 1990s, this problem has been solved when the State Council revoked the industry departments and given the universities subordinate to the industry departments to the local government by merging and co-building the universities. therefore,the principle of "the leadership of the party"was insisted on the management of the universities. Placing cadres under party supervision is the tradition of the old liberated areas. in the highly political atmosphere of learning from the Soviet Union, it is very important to implement the rule in the universities. asXie Yong said, the prelude to the department adjustment in 1952 is the movement of the brainwashing of the intellectuals. from the department adjustment,we can see that the new regime was trying to decentralize the liberal intellectuals who were educated during the late national government(XieYong. 2007). The alertness of the ideology can be seen in the movement of learning from the Soviet Union everywhere. The imitation of the Soviet Union also found expression in the division of the personnel system of the universities and the Academy of Science,the universities Give priority to teaching and the Academy of Science the research. so,the teaching and the research were divided.

\section{The Influence of the Soviet Union on the Micro Personnel System in Chinese Universities}

The influence of the Soviet Union on the micro personnel system in Chinese universities is as follows:

\subsection{The Soviet Union Influenced the Setting of the} Teaching Research Team

One of the important influence of the Soviet Union on the organization of the Chinese universities is the setting of the teaching research team, this makes the internal organization system of the Chinese universities evolved into university - department teaching research team. The teaching research team, the full name of the teaching research steering team, is set up in the background as follows: all the Chinese universities across the country were conducting the teaching system reform with the center of major setting up, using the textbooks, syllabus, and teaching plan of the former Soviet Union, learning the teaching method of the former Soviet Union Therefore, the form of the teaching organization of the former Soviet Union should be introduced .All this completely changed the grass-root organizations of the Chinese universities. From the relevant clauses 
of the three files in 1950 to 1956 , you can see that the teaching research steering team is named after the prescribed courses, the members are all the teachers of the same course or similar course, including professors, associate professors, lecturers, teaching assistants and graduate students. One director will be appointed by the principal, and reported to the Ministry of Education or the competent authority for the record (the director of the course of the political theory should be approved by the superior departments).The director is generally held by a professor, in particular cases, the director can be held by an associate professor or a lecturer. The teaching research team is actually an organization of teaching,its main task is to research the teaching method, direct the teachers'teaching research activities, and guide students to learn and the graduate students education, etc. Under the great promotion of the government,the teaching research team has been set up in all the universities across the country until 1956. During the time the teaching team coexist with the teaching research team. The purpose of the setting up of the teaching team is to organize the teachers to reform the content of courses,but the activities of the teaching team are limited to the teaching, it can't play the role of a fundamental organization.The establishment of the teaching research team makes all the teachers including the experts from the former Soviet Union merged into one team, which greatly changed the form of the activities of the teachers. Formerly,teachers' activities, especially the teaching activity is determined by himself, after the setting up of the teaching research team, the lecture content, the teaching method must be decided by the teaching research team, in this case,the teaching become a collective activity

\subsection{The Soviet Union Influenced the Change of the Staff' Identity}

The department adjustment carried out in accordance with the university system of the Soviet Union in 1952 made all the Chinese universities become public, and the teaching and administrative staff in Chinese universities also changed the identity from the freelancers of the Republic of China to the state functionaries of the People's Republic of China. The change of the staff' identity began in 1952. Before 1952, the original colleges and universities were took over by the new China . In the department adjustment in 1952 , the name of the private colleges and universities (including the church universities) were removed, the departments and the staff of the private colleges and universities were respectively merged into public ones, so the second personnel allocation of all the universities were achieved,the staff of all the universities became the national workers. In other words, the department adjustment not only eliminated the private universities $40 \%$ of the total universities before) on the organizational and physical form,but also changed the identity of the staff in colleges and universities.

\subsection{The Implementation of the Teaching Workload System Is One of the Influence of the Soviet Union}

One of the important influence of the Soviet Union is that the teaching workload system was introduced in 1954. In fact, in the articles of association of the Imperial University in late Qing Dynasty and the various rules and regulations of the university of the Republic of China, we can see the rules which command the teachers to have some amount of the lessons at least a week. But the teaching workload system was clearly proposed after the new China began to learn from the Soviet Union.The purpose of 
establishing teachers' workload system is "to follow the example of the former Soviet Union", "strengthen the planning of higher education", "develop the teachers' potential" gradually realize the salary system in which recompense is made according to the amount of labor expended". In spite of a variety of reasons, the implementation of the teaching workload system in 1957 were stopped, until now, many colleges and universities still have a rule about the teachers' workload in a semester or a school year clearly or vaguely.The introduction of the concept of the teaching workload is helpful to the universities' scientific management.

\subsection{The Soviet Union Influenced the Chinese} Teachers' Development

One of the important form of the teachers' development is to employ the foreign experts to give lectures or to send the teachers to study abroad. The influence of the Soviet model on the teachers' development is as follows:Firstly,the employment of the Soviet experts make the Chinese teachers not only adopt the teaching method of the Soviet union, but also have Russian as their first language. In Chinese history ,there are two periods in which foreign teachers and experts were hired in large-scale,one is late Qing Dynasty in which the government hired the Japanese teachers, the other is early People's Republic of China in which Soviet experts were employed in large-scale. Japanese teachers were generally employed to teach a course, and the Soviet experts not only give a class, but also "guide the undergraduate teaching, guide the revision of the teaching plan and the syllabus, help to cultivate the teachers and graduate students. The number of the Soviet experts is large, only in1953-1956, 528 Soviet experts were hired ; and the Soviet experts covered a range of disciplines,such as engineering, science, finance and economics, politics and law, normal, agriculture and forestry, Russian. Among them, the engineering experts are at most, $42 \%$ of the total number, Russian the second, accounting for $18.8 \%$.Secondly, the Soviet Union basically became the only country the Chinese teachers go abroad to communicate with. During the period learning from the Soviet Union,the new China basically associate with the socialist countries. In 1950-1965 ,the students studying in the Soviet Union (the students are mainly university teachers) account for $80 \%$ of the Chinese overseas students, the other 20\% is mostly sent to the Eastern European countries such as Poland, the Czech republic, Bulgaria, etc (XieXuefeng. 2004).

\subsection{The Introduction of the Academic title System} Is One of the Influence of the Soviet Union

Academic title system as one of the Soviet Union model ,similar to the teachers' professional qualification system, was just tried to introduced into China, and had not been executed. The Ministry of Education successively formulated three files in 1954 and 1956 ,and set up the drafting committee of the honorary title such as"degree, academic rank, engineering experts", tried to promote the academic title system. but because the movement of "antirightist" started in 1957, the work about the teachers' promotion and the academic title system stopped,so these files above wasn't put into effect (Zhang Renxian. 1995). Academic title is the name of the academic position awarded by the "academic level, working ability and working achievement”. The characteristic of the Soviet academic title system is as follows:firstly, the academic, technical level is the main basis of granting and promotion;secondly, no number limited;thirdly, the winner will have the title 
for life once awarded;fourthly,the academic title can be used as the basis of salary, life, and the political treatment.The degree is emphasized. Having a degree is the prerequisite for the academic title,and obtaining a job in an university is closely related to the degree, academic title. This emphasis on the degree and no limiting to the number is different from the system of university teachers titles implemented in China before.

\section{Conclusions}

The personnel system of foreign universities can survive in China, two conditions are required:firstly,there is the consistency of the idea,that is to say, the personnel system can match the politics, economy, especially the culture of China. some system can be accepted by Chinese just because China has similar practice before.For example, the department management system of the Soviet Union, China had the similar practice in Tang Dynasty.Then,the full-time administrative machinery have the colleges as an attached institution,such as the medical school attached to the Imperial Medical Agency, the divination school attached to the Imperial Augury Agency Academy,the music, dance and art school attached to the Imperial Musical Agency,the astronomy, calendar and clepsydra school attached to the Imperial Astronomic Agency, the School of Veterinary Medicine attached to the Imperial Veterinary Medicine Agency,etc. There are learned scholars ,teaching assistants and students in all the schools (Sun Peiqing. 2006). The Japanese system of the civilian officials is similar to the traditional one of the Chinese educational officers. The reason that the systems of French university district and Soviet teaching workload can't come into effect in China is that they are inconsistent with Chinese tradition.As a famous Japanese educationist said,"even if you can imitate the good formal rules, if the local informal rules have the difficult to change for a short while because of the inertia, the new formal rules and the old informal rules will inevitably produce conflict."As a result, the borrowed system can't perform( Zhou Li-An. 2001). Secondly,there are the actors who can accept and practice the foreign country's education idea. The famous Chinese university President Zhu Jiu Si once said"The reason of China's imitation of the Soviet Union in early People's Republic of China is mainly the politics. In some way,politics is the only reason ,no other reasons" It is the Chinese government to strongly push the change.

\section{Acknowledgment}

Financed by Chinese Ministry of Education Humanities and social science Fund Youth Project in 2013: Research on the Change of the personnel system in Chinese universities in the perspective of HistoricalInstitute ( 13 YJC880084 ) .

\section{References}

[1] Sun Peiqing.History of Chinese Education[M]. Shanghai:East China Normal University Press, ,2006:155

[2] XieXuefeng. From Learning from the Soviet Comprehensively to Independent Choice: Chinese Higher Education and the Soviet Model[M]. Wuhan:Huazhong University of Science and Technology Press, 2004:75

[3] Xie Yong.Chinese Universities: When the tradition was interrupted $[\mathrm{J}]$. Journal of the Same Boat, 2007 (5)

[4] Zhang Renxian. Pandect about the School Personnel Management[M]. Beijing: China Personnel publishing house, 1995:252 
[5] Zhou Li-An. Comparative Institutional Analysis

[M]. Shanghai: Far East Publishing House, 2001:

172 